\title{
Editorial: Missed and New Opportunities in World Trade
}

\author{
CsONGOR István NAGY*
}

International trade has recently seen turbulent times. It has been subject of heated political and social debates and has generated an animated scholarly discourse. It is not an exaggeration to say that international trade is entering into a new age, where tariffs are no longer the major constraints (though they may still be high in certain sectors) and states endeavor to gain additional benefits through boosting trade via diminution of non-tariff barriers.

In this era, bilateralism and regionalism carries the day. In line with the Doha Trade Round's balking, which made the furtherance of the global multilateral system stall, a new generation of free trade agreements has been emerging. These agreements are comprehensive, ambitious, cover the whole spectrum of trade items (goods, services, technology, capital etc.) and have the makings of creating a new governance for international economic relations.

This story, as noted above, no longer centers around tariffs and quotas. Though customs duties have certainly not lost their relevance, they share the scene with various other issues, such as regulatory cooperation, protection of value standards (labor rights, environmental protection), investment protection, public procurement, to mention a few. All this necessarily imposes further limits on national regulatory autonomy and calls for the re-conceptualization of the fundamental notions of global governance, state sovereignty and regulatory autonomy.

Nonetheless, new generation free trade agreements' reception has not been devoid of social outcry and political upheaval. The United Kingdom's secession from the European Union and the new US administration's policy to call off the EU-US Free Trade Agreement (Transatlantic Trade and Investment Partnership, TTIP), cancel the Trans-Pacific Partnership Agreement (TPP) and renegotiate the North American Free Trade Agreement (NAFTA) all prove that the reception of the new era of free trade has not been every time positive.

New generation or next generation free trade agreements have brought about harsh criticism from various angles, mainly because of their tendency to deal with numerous issues beyond trade proper.

* Csongor István Nagy, LL.M., Ph.D., S.J.D, dr. juris is professor of law and head of the Department of Private International Law at the University of Szeged and research chair and the head of the Federal Markets 'Momentum' Research Group of the Hungarian Academy of Sciences, and an attorney-at-law admitted to the Budapest Bar. He is recurrent visiting professor at the Central European University (Budapest/New York), the Riga Graduate School of Law (Latvia) and the Sapientia University of Transylvania (Romania). Email: csongor.nagy@gmail.com. This thematic issue (Missed and new opportunities in world trade. Eds. Csongor István Nagy \& Zoltán Víg) was published as part of the research project of the HAS-Szeged Federal Markets 'Momentum' Research Group. 
Let me come to TTIP. I think that's a particularly bad agreement. And let me say why. It's not about trade. Trade barriers between Europe and America, tariffs have already come down, basically, very, very well. Little changes in the exchange rate do more to change competitivity than wiping out the tariffs. So, the fact is that the instability in exchange rates caused by lack of harmonization in monetary policy is a far bigger impediment to trade than any of the tariffs. (...) So this is an attempt to increase the power of corporations to run our economies and our societies. It's not a trade agreement. $^{1}$

The spearhead of the criticism is national regulatory sovereignty, democratic legitimacy and the distrust in foreign standards.

[These agreements are] no ordinary free trade deal[; they raise] questions about the political future of independent nations, about sovereignty, democracy and indigenous self-determination, and, above all, the people's right to know what governments are doing. ${ }^{2}$

The proposed trade deal is a huge threat to our democracy and our sovereignty. We have seen the UK participating in a disastrous race to the bottom on corporate tax rates and wages. We must not also walk into lowering our workers' rights, environmental standards and food health standards. Chicken carcasses washed in bleach, hormone-stuffed beef and open season on pollution are not things we want to import from the US. ${ }^{3}$

The apocalyptical visions on international trade's impact on national sovereignty and democracy seem to be highly excessive, in particular because there is nothing in these agreements making subsequent rectification, correction or even denunciation impossible. Still, it has to be made clear that there is, indeed, an inverse proportionality between the wealth benefits of trade and national regulatory sovereignty. A level playing field necessitates a framework based on rules, and rules, even if accepted voluntarily, do limit the freedom of action of those who agreed to them.

Unfortunately, there is no way to boost the fruit-bearing of trade, while treating national regulation untouchable. Free trade agreements prohibit the use of regulation for protectionist purposes, consequently, national measures restricting trade may have to be justified and defended before a dispute settlement body. Free trade surely does not put up with unlimited national regulatory sovereignty. Still, though much depends on the details of

1 An Interview with Nobel Laureate Joseph Stiglitz: The loss of the American Dream, Trickle Down Economics and Free Trade, presented by General Economic Dynamics, 6 October 2015. <https:// ged-project.de/videos/competitiveness/an-interview-with-nobel-laureate-joseph-stiglitz/>. A transcript of the interview is available at íhttps://citizenactionmonitor.wordpress.com/2015/12/16/nobel-laureateeconomist-joseph-stiglitz-heaps-scorn-on-tpp-and-ttip/> both accessed 17 November 2017.

2 Jane Kelsey, No Ordinary Deal: Unmasking the Trans-Pacific Partnership Free Trade Agreement (Bridget Williams Books with the New Zealand Law Foundation, 2010).

3 Natalie Bennett, Green Party leader, quote available at $<$ http://www.bbc.com/news/ukpolitics-30493297> accessed 17 November 2017. 
the architecture, this does not imply that states are deprived of the possibility to pursue local legitimate ends.

Recent developments also suggest that the internationalization of free trade can be slowed down but cannot be halted. Xi Jinping, the president of the People's Republic of China, noted that '[p]ursuing protectionism is just like locking oneself in a dark room.'4 Indeed, missed opportunities may give rise to new opportunities for others.

All in all, the process of trade liberalization did not stall. Though after a tumultuous process, the Canada-EU Free Trade Agreement (Comprehensive Economic and Trade Agreement, CETA) was finally signed and provisionally went into effect on 21 September $2017 .{ }^{5}$ In the same vein, negotiations for the EU-Japan Economic Partnership Agreement were finalized on 8 December 2017. The JEFTA will be submitted for approval to the European Parliament and the EU Member States by the European Commission after the legal verification and translation processes. ${ }^{6}$

The withdrawal of the US from the TPP did not to put an end to the trans-pacific initiative but simply brought about an economic region without the US (TPP 12-minus-one agreement). The remaining 11 signatories went on with the project without the $\mathrm{US}^{7}$ and in January 2018 agreed to conclude the TPP-11, renamed as Comprehensive and Progressive Agreement for Trans-Pacific Partnership (CPTPP), the formal signing ceremony to be in March 2018. ${ }^{8}$

It should not be disregarded that nowadays trade liberalization is not only about what to gain but also about what to lose.

Whoever stays out misses out. Not being part of a free trade zone confers a competitive disadvantage. It is widely accepted that free trade agreements have significant trade

4 Tharoor, Ishaan, 'China casts a long shadow over Trump and Davos' (26 January 2018), available at $<$ https://www.washingtonpost.com/news/worldviews/wp/2018/01/26/china-casts-a-longshadow-over-trump-and-davos/?utm_term=.35bd8cf722b2> accessed 27 January 2018.

${ }^{5}$ Council Decision (EU) 2017/38 of 28 October 2016 on the provisional application of the Comprehensive Economic and Trade Agreement (CETA) between Canada, of the one part, and the European Union and its Member States, of the other part. OJ L 11, 14.1.2017, p. 1080-1081. See Press Release: EU-Canada trade agreement enters into force (20 September 2017), available at $<\mathrm{http} / /$ trade.ec.europa.eu/doclib/press/index.cfm?id $=1723>$ accessed 17 November 2017. CETA is a mixed agreements which comes under both EU and Member State competence, it may go into effect only once it is approved in all the Member States. Since these approval procedures may take numerous years, the EU Council, as allowed for by Article 30.7 (Entry into force and provisional application), made those elements of the CETA that come under EU competence provisionally applicable, until final approval is pending in Member States. Provisions not yet in force concern investment protection, market access for portfolio investment (with the exception of foreign direct investment, as this comes under exclusive EU competence) and the Investment Court System.

${ }^{6}$ Press Release: EU and Japan finalise Economic Partnership Agreement (8 December 2017), available at $<\mathrm{http} / / /$ trade.ec.europa.eu/doclib/press/index.cfm?id=1767> accessed 31 December 2017.

7 Shaffer, Sri Jegarajah, Craig Dale, Leslie (2017-05-21). 'TPP nations agree to pursue trade deal without US'. CNBC <https:/www.cnbc.com/2017/05/20/tpp-nations-agree-to-pursue-trade-dealwithout-us.html $>$ accessed 17 November 2017.

8 Swick, Brenda C. and Augruso, Dylan E., 'Canada Reaches Comprehensive and Progressive Trans-Pacific Partnership Agreement' (29 January 2018), available at <https://www.natlawreview. com/article/canada-reaches-comprehensive-and-progressive-trans-pacific-partnership-agreement $>$ accessed 30 January 2017. 
diversion effects. ${ }^{9}$ Under the CPTPP, Japanese enterprises may purchase Australian products even if they are more expensive than the American ones. The former carry no tariff burden and may be more compliant with Japanese standards. It is not a surprise that there is a global rush for membership in trading clubs. ${ }^{10}$

Furthermore, trade is not only about the benefits of local consumers in the form of enhanced surplus due to lower prices. In the global factory, having cheap input products determines the competitiveness of the output products. It might be painful to see that a high-wage country's company outsources elements of the production process to a low-wage country, thus 'taking jobs away'. However, preventing them from doing that generates higher manufacturing costs, while in the world market they have to compete with companies which do take advantage of the cost-benefits of low-wage countries. Again, whoever stays out misses out.

This special issue addresses selected aspects of international trade's above developments with papers on Africa, the Americas, Asia and Europe. It is based on the proceedings of an international conference that took place on 12 April 2017 at the University of Szeged, entitled 'Missed and new opportunities in world trade: is Trump China's trump in world trade?'.

The first paper, 'Multilateralism and Regionalism in International Trade Law', is authored by Professor János Martonyi, Hungary's former minister of foreign affairs and professor emeritus at the University of Szeged. The author gives an account of the growing economic, political, ideological, institutional and legal challenges of international trade.

Professor Stefan Messmann, former professor of the Central European University and former Deputy General Manager and Commercial Executive with Shanghai Volkswagen, in his paper entitled 'A German Lawyer in the Far East: Investing and Doing Business in China', gives an insider's overview on the comprehensive issues of investing in China through the lenses of a practicing lawyer.

The paper of Professor Harrison O. Mbori (Strathmore University Law School, Nairobi, Kenya), 'Combating Unjustified Sanitary and Phytosanitary Measures in the African Tripartite Free Trade Area (COMESA-SADC-EAC): SPS-Plus or SPS-Minus?', addresses the hot issue of sanitary and phytosanitary measures from an African perspective.

9 See Viner, Jacob, 'The Customs Union Issue' (1950) 4 Journal of the History of Economic Thought 491-515 (1950); Lipsey, Richard G., 'The Theory of Customs Unions: Trade Diversion and Welfare' (1957) 93 Economica New Series 40-46; O’Brien, Denis P., 'Customs Unions: Trade Creation and Trade Diversion in Historical Perspective' (1976) 4 History of Political Economy $540-63$.

10 See Gantz, David on Ford in China (comment posted on 22 June 2017), available at $<$ http://worldtradelaw.typepad.com/ielpblog/2017/06/david-gantz-on-ford-in-china.html $>$ accessed 20 November 2017:

Am I missing something with the announcement that Ford will build a new plant in China to build the next generation small car (Focus)? I believe that this was the plant that Ford originally planned for Mexico, but changed its mind after criticism from Mr. Trump. (Apparently, Ford's existing US plants are busy with much more profitable SUVs and small trucks.) It seems to me that the major result of the decision to build the plant in China rather than in Mexico is that while the vehicles produced in the Mexican plant would likely have used 35-40\% US parts and components (to meet the $62.5 \%$ NAFTA value added requirements), the Chinese made Focuses will likely have little or no US parts content. Ford will probably save enough money in using cheaper Asian parts to more than offset to $2.5 \%$ duty assessed when the finished vehicles enter the United States. Somehow, this doesn't seem the best way to preserve manufacturing jobs in the US. Or am I missing something? 
The paper of Dr. Sanford U. Mba (doctoral researcher at the Central European University), 'Africa for the Chinese'? Revisiting Sino-African Bilateral Investment Treaties', deals with the intensive trade and economic relations between Africa and China, which resulted in a huge influx of foreign direct investment from China to African states. It analyses the challenges raised by standard BITs and how China-Africa BITs have dealt with those challenges.

Professor Manuel A. Gómez, Associate Dean at Florida International University's College of Law, in his paper titled 'The South American way: sub-regional integration under ALBA and UNASUR and international dispute resolution', analyses two of the most recent South American sub-regional integration efforts: ALBA and UNASUR.

The paper of Professor Zsolt Bujtár and Professor András Kecskés, titled 'Hedging your bets? - An overview of the legal aspects of hedge funds', gives an outline of certain legal aspects of hedge funds as a controversial element of the global financial system.

The special issue's concluding paper, authored by Professor Zoltan Víg (University of Szeged) and Professor Tamara Gajinov (Union University, Serbia), titled 'Challenges Facing China', address the future prospects of one of the globe's largest economic giants. It examines economic and other challenges that China is facing. such as the completed cycle as a high-growth-low-wage country, corruption, lack of cheap labor-force, lack of market liberalization and political issues. 